\title{
Transplantacijski program za bubreg u Kliničkom bolničkom centru Osijek
}

Kidney transplantation program in University Hospital Centre Osijek

\author{
Goran Samardžija ${ }^{1 *}$, Lada Zibar ${ }^{2,3}$, Damir Prlić1,3, Bojan Sudarevićc ${ }^{1,3}$, Ivan Ćosić1,

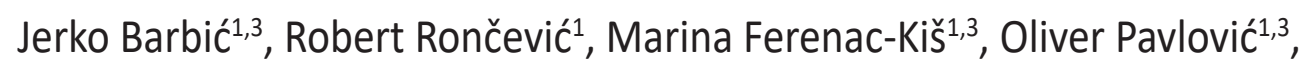 \\ Marina Samardžija ${ }^{1,3}$, Josip Perkovići,3
}

Sažetak. Cilj: Klinički bolnički centar (KBC) Osijek najmlađe je transplantacijsko središte za bubreg u Hrvatskoj. Prva presadba (TX, od engl. transplantation) u Osijeku učinjena je 2007. godine, u godini ulaska Hrvatske u Eurotransplant. Cilj istraživanja je prikazati rezultate transplantacije bubrega u KBC-u Osijek, od prve transplantacije učinjene 2007. godine do siječnja 2020. godine. Ispitanici i metode: U istraživanje su bili uključeni svi ispitanici (144) kojima je učinjena transplantacija bubrega u KBC-u Osijek. Iz medicinskih zapisa prikupljeni su demografski i medicinski podatci, vremenski podatci o dijalizi i TX-u te kreatininemiji kao mjeri funkcije presatka. Analiza preživljenja učinjena je Kaplan-Meierovim testom. Rezultati: Jednogodišnje preživljenje presatka cenzurirano za smrt s funkcionirajućim presatkom bilo je $93,8 \%$, a petogodišnje $88,9 \%$. Tijekom medijana praćenja od 7 godina (interkvartilni raspon, IQR, od engl. interquartile range, 4 - 9 godina), od min. 0 godina do maks. 13 godina, preživljenje pacijenata $s$ funkcionirajućim presatkom bilo je $86,8 \%$. Medijan kreatininemije godinu dana nakon TX-a bio je $132 \mu \mathrm{mol} / \mathrm{I}$ (IQR $100-174 \mu \mathrm{mol} / \mathrm{l}$ ), od min. $48 \mu \mathrm{mol} / \mathrm{l}$ do maks. $492 \mu \mathrm{mol} / \mathrm{l}$, a nakon pet godina $120 \mu \mathrm{mol} / \mathrm{I}$ (IQR $103-161 \mu \mathrm{mol} / \mathrm{I})$, od min. $53 \mu \mathrm{mol} / \mathrm{I}$ do maks. $341 \mu \mathrm{mol} / \mathrm{l}$. Zaključak: Rezultati bubrežnog TX-a u KBC-u Osijek bili su na razini europskih rezultata.

Ključne riječi: bubrežna presadba; funkcija bubrežnog presatka; Hrvatska; Osijek; preživljenje pacijenata s bubrežnim presatkom; preživljenje bubrežnog presatka

Abstract. Aim: University Hospital Centre (UHC) Osijek is the youngest kidney transplantation center in Croatia. The first transplantation (TX) was performed in 2007, the same year when Croatia joined Eurotransplant. The aim of this study is to present results of kidney TX in UHC Osijek from the first TX in 2007 till January 2020. Patients and methods: The study included all 144 patients that underwent kidney TX in UHC Osijek. Data on demographics, medical, dialysis and TX times data and creatininemia (as the measure of kidney transplant function) were taken from medical records. Survival analysis was performed by Kaplan-Meier test. Results: Kidney transplant survival censored for death with functioning transplant was 93.8 $\%$ at 1 year and $88.9 \%$ at five years. During the median follow-up time of 7 years (interquartile range, IQR, $4-9$ years), from min. 0 years to max. 13 years, survival of patients with functioning transplant was $86.8 \%$. Median creatininemia at 1 year after TX was 132 $\mu \mathrm{mol} / \mathrm{I}$ (IQR 100 - $174 \mu \mathrm{mol} / \mathrm{I})$, from $\mathrm{min} .48 \mu \mathrm{mol} / \mathrm{I}$ to $\max .492 \mu \mathrm{mol} / \mathrm{I}$, and $120 \mu \mathrm{mol} / \mathrm{I}$ (IQR $103-161 \mu \mathrm{mol} / \mathrm{l})$, from min. $53 \mu \mathrm{mol} / \mathrm{l}$ to $\max .341 \mu \mathrm{mol} / \mathrm{l}$, at 5 years. Conclusion: Results of kidney TX in UHC Osijek were similar to European results.

Key words: Croatia; kidney transplantation; kidney transplant function; kidney transplant patient survival; kidney transplant survival; Osijek
${ }^{1}$ Klinički bolnički centar Osijek, Osijek, Hrvatska

${ }^{2}$ Klinička bolnica Merkur, Zagreb, Hrvatska

${ }^{3}$ Medicinski fakultet Osijek, Sveučilište Josipa Jurja Strossmayera u Osijeku, Osijek, Hrvatska

\section{*Dopisni autor:}

Mr. sc. Goran Samardžija, dr. med. KBC Osijek, Huttlerova 4, 31000 Osijek E-mail: sgoran1961@gmail.com

http://hrcak.srce.hr/medicina 


\section{UVOD}

Klinički bolnički centar (KBC) Osijek četvrto je i najmlađe transplantacijsko središte za bubreg u Hrvatskoj. Početak transplantacije (TX, od engl. transplantation) u Osijeku podudara se s ulaskom Hrvatske u Eurotransplant 2007. godine.

Povijest osječke bolnice datira još od 1749. godine kada je osnovano ubožište, što je predstavljalo prvu građansku bolnicu. Kasnije kožar Josef Huttler, gostioničar Johann Kohlhofer i isusovac Cri-

Klinički bolnički centar (KBC) Osijek je četvrto i najmlađe transplantacijsko središte za bubreg u Hrvatskoj. Početak transplantacije (TX, od engl. transplantation) u Osijeku podudara se s ulaskom Hrvatske u Eurotransplant 2007. godine. stian Monsperger osnivaju zakladu u vezi s kojom se tek 1874. godine gradi Huttler - Kohlhofer Monspergerova zakladna bolnica (na današnjem mjestu). Tada je to bila najljepša i najmodernija bolnica na jugoistoku Europe, s 200 kreveta, operacijskom dvoranom, odjelom za duševne pacijente i odjelom za lues ${ }^{1}$. U novijoj povijesti važnu ulogu razvoju medicine u Osijeku ima osnivanje Medicinskog fakulteta 1979. godine (u početku dislocirani studij Sveučilišta u Zagrebu) koji 1998. prerasta u Medicinski fakultet Sveučilišta Josipa Jurja Strossmayera u Osijeku². Ubrzo Klinička bolnica Osijek (koja je kliničkom postala 1992. godine) prerasta u KBC (2009.), što daje novi zamah znanstvenoistraživačkom i stručnom radu.

Povijest nadomjesnog bubrežnog liječenja u Osijeku je za hrvatske, ali i svjetske prilike gotovo pionirska. Urološki odjel osječke bolnice započinje s hemodijalizom (HD) 1969. godine pod vodstvom kirurga i urologa prim. dr. Ignaca Stipanića, tadašnjeg rukovoditelja toga odjela, tek koju godinu nakon Rijeke, u kojoj je uvedena prva dijaliza u našoj državi. Od 1982. godine u KBC-u Osijek izvodi se i peritonejska dijaliza (PD), vremenski također u skladu sa sličnom rutinom u zemlji i svijetu. Prve eksplantacije u osječkoj bolnici izvedene su prije Domovinskog rata (1989.), no s TX-om smo zbog rata izgubili korak i s Rijekom (prva transplantacija bubrega 1971. godine) i sa Zagre- bom (prva transplantacija bubrega 1973. godine). Danas je KBC Osijek značajno darivateljsko središte. Darivateljski program pod vodstvom je bolničkog koordinatora i odvojen je od transplantacijskoga, kako je to ustrojeno i na državnoj razini. Prva transplantacija bubrega je u KBC-u Osijek izvedena 2007. godine pacijentici staroj 53 godine i liječenoj hemodijalizom 11 godina. Presadak je imao 4 arterije, 2 vene i 2 uretera. Urološkom timu pomogli su tada iskusni urolozi iz KBC-a Zagreb (prof. dr. sc. Željko Kaštelan i dr. sc. Hrvoje Šošić), a u nastavku transplantacijskog programa ključan je godinama bio prof. dr. sc. Petar Orlić, po umirovljenju angažiran educirati osječke urologe za izvođenje ovih kirurških zahvata. Prvi je zahvat protekao uredno, a bubreg je unatoč primarno marginalnoj kakvoći funkcionirao sljedećih 7 godina.

Zavod za urologiju KBC-a Osijek ima urološke timove za transplantaciju bubrega, kao i prostorne i tehnološke uvjete. KBC Osijek kao transplantacijsko središte ima vlastitu „listu“ čekanja za transplantaciju bubrega, u okviru Eurotransplanta ${ }^{3}$. Na tu „listu“ može biti uvršten bilo koji pacijent državljanin Hrvatske bez obzira gdje bio na kroničnom programu dijalize. Alokacija presatka određena je prema zajedničkom načelu za cijelu Hrvatsku, neovisno o tomu na čijoj se „listi“ u našoj državi pacijent nalazio, u skladu sa sustavom bodovanja Eurotransplanta, u središtu Eurotransplanta u Leidenu. Danas je moguće registrirati pacijenta na „listi“ i preemptivno, odnosno i prije početka liječenja dijalizom. Tipizacija tkiva i druge pretrage iz tog se područja za pacijente s osječke „liste“ rade u KBC-u Zagreb, a analogni laboratorij KBC-a Osijek je u postupku akreditacije za ove dijagnostičke pretrage.

Nefrolozi KBC-a Osijek od početka su transplantacijskog programa koordinatori s Eurotransplantom, te su na dužnosti 24 sata svih 365 dana u godini. Prijetransplantacijsku obradu i imunosupresivno liječenje, ultrazvučne i ambulantne kontrolne preglede, biopsije presatka i liječenje nekirurških komplikacija također provode nefrolozi Zavoda za nefrologiju KBC-a Osijek. Danas se u ambulanti za transplantirane pacijente prati više od 200 pacijenata. Iskustvo praćenja i kontrole transplantiranih bubrežnih pacijenata traje 
barem 3 posljednja desetljeća, još od vremena kada su prvi pacijenti s osječke dijalize bili transplantirani u Rijeci, Zagrebu ili inozemstvu (najčešće u Austriji - Beču, ali i Indiji).

Danas je Hrvatska po TX-u najuspješnija država u Eurotransplantu, Europi i svijetu, a pacijentima iz Slavonije i Baranje bubrežni presadak dostupan je u bliskom mjestu, odnosno u Osijeku, kao i sva prije- i poslijetransplantacijska skrbb ${ }^{4,5}$. Dio liječnika iz transplantacijskih timova su sveučilišni nastavnici Medicinskog fakulteta Sveučilišta Josipa Jurja Strossmayera u Osijeku i tako sudjeluju u edukaciji studenata i specijalizanata o transplantacijskoj medicini. Transplantacijski su liječnici u KBC-u Osijek također aktivni u znanstvenim i stručnim istraživanjima u području TX-a, kao i u popularizaciji TX-a u javnosti. Sudionici su i domaćih i međunarodnih transplantacijskih skupova i predstavnici osječkog transplantacijskog programa u Eurotransplantu, a svoje transplantacijsko znanje usavršavaju i praćenjem relevantnih publikacija kao i boravcima u drugim domaćim i inozemnim transplantacijskim središtima.

U ovom članku prikazujemo ishode transplantacije bubrega u KBC-u Osijek od prve transplantacije učinjene 2007. godine do siječnja 2020. godine.

\section{ISPITANICI I METODE}

Istraživanje je provedeno na Zavodu za nefrologiju Klinike za internu medicinu KBC-a Osijek.

$U$ istraživanje su bili uključeni ispitanici kojima je učinjena transplantacija bubrega s umrlog darivatelja od početka transplantacijskog programa za bubreg u KBC-u Osijek do siječnja 2020. godine. (20. listopada 2007. - 31. siječnja 2020.). Ukupno je učinjeno 144 transplantacija, a nekim ispitanicima bila je to druga ili treća transplantacija.

Iz medicinskih zapisa prikupljeni su demografski i medicinski podatci, vremenski podatci o dijalizi i TX-u te kreatininemiji kao mjeri funkcije presatka. Svi ispitanici u istraživanju potpisali su informirani pristanak kojim dozvoljavaju uporabu podataka iz medicinskih zapisa za znanstvena istraživanja. Podatci su anonimizirani.

\section{Statistika}

Podatci su prikazani deskriptivno i obrađeni analitički. Nominalni podatci prikazani su pomoću apsolutnih i relativnih učestalosti. Numerički podatci prikazani su medijanom i interkvartilnim rasponom (IQR, engl. interquartile range). Normalnost raspodjele testirana je Kolmogorov-Smirnovljevim testom. Preživljenje je istraženo analizom preživljenja - Kaplan-Meierovovim testom. Za statističku obradu podataka korišten je program SPSS for Windows, inačica 16.0, SPSS Inc., Chicago, IL, Sjedinjene Američke Države (SAD).

\section{REZULTATI}

U istraživanje su bili uključeni svi pacijenti (144) kojima je učinjena transplantacija bubrega u KBC-u Osijek od početka transplantacijskog programa za bubreg do siječnja 2020. godine (od 20. listopada 2007. do 31. siječnja 2020. godine). Demografska obilježja primatelja i darivatelja bubrega prikazana su u tablici 1 . Od 144 pacijenta, njih 60,4 \% bili su muškarci. Za 131 pacijenta (91\%) to je bio prvi, za 10 (6,9\%) drugi, a za 3 (2,1\%) treći bubrežni presadak. Medijan dobi pacijenata u trenutku TX-a bio je 53 godine (IQR 47 - 60 godina), od min. 27 godina do maks. 84 godine. Medijan praćenja od dana TX-a do zaključno 31. siječnja 2020., do gubitka funkcije presatka ili do smrtnog ishoda, iznosio je 7 godina (IQR 4 - 9 godina), od min. 0 godina do maks. 13 godina. Prije bubrežnog TX-a 126 (88,5 \%) pacijenata bilo je na hemodijalizi, a $18(12,5 \%)$ na peritonejskoj dijalizi.

Raspodjela broja TX-a prema godinama prikazana je na slici 1. Najviše TX-a bilo je 2011. godine, dvadeset i jedna (14,6\%). Prosječno se godišnje transplantira 11 pacijenata (medijan), IQR 9 - 14 pacijenata, od min. 5 pacijenata do maks. 21 pacijenta.

Medijan dobi darivatelja u trenutku TX-a bio je 52 godine, s IQR-om od 42 do 59 godina (od min. 16 godina do maks. 75 godina).

Do siječnja 2020. umrlo je 19 od 144 (13,2 \%) transplantiranih pacijenata $s$ funkcionirajućim presatkom. Uzrok smrti pacijenata s funkcionirajućim presatkom najčešće je bila sepsa (6 pacijenata, 4,2\%), srčani udar (5 pacijenata, 3,5\%), zloćudna bolest (2 pacijenta, 1,4\%), plućna embolija ( 2 pacijenta, 1,4\%), citomegalovirusna bolest ( 2 pacijenta, 1,4\%) te nepoznati uzrok u 2 pacijenta $(1,4 \%)$. 
Tablica 1. Demografska obilježja primatelja i darivatelja bubrega $(N=144)$

\begin{tabular}{|c|c|c|}
\hline \multirow{3}{*}{$\begin{array}{l}\text { Vrsta dijalize } \\
\text { n (\%) }\end{array}$} & hemodijaliza & $126(88,5)$ \\
\hline & peritonejska & $18(12,5)$ \\
\hline & preemptivno & 0 \\
\hline \multirow{2}{*}{$\begin{array}{l}\text { Spol primatelja } \\
\text { n (\%) }\end{array}$} & M & $87(60,4)$ \\
\hline & Ž & $57(39,6)$ \\
\hline \multirow{2}{*}{$\begin{array}{l}\text { Spol darivatelja } \\
\text { n (\%) }\end{array}$} & M & $91(63,2)$ \\
\hline & ž & $53(36,8)$ \\
\hline \multirow{3}{*}{$\begin{array}{l}\text { Broj transplantacija } \\
\text { n (\%) }\end{array}$} & 1. transplantacija & $131(91)$ \\
\hline & 2. transplantacija & $10(6,9)$ \\
\hline & 3. transplantacija & $3(2,1)$ \\
\hline \multirow{4}{*}{$\begin{array}{l}\text { Podudarnost prema spolu } \\
\text { n (\%) }\end{array}$} & primatelj $\mathrm{M}$, darivatelj $\mathrm{M}$ & $55(28,2)$ \\
\hline & primatelj Ž, darivatelj Ž & $21(14,6)$ \\
\hline & primatelj M, darivatelj Ž & $32(22,2)$ \\
\hline & primatelj Ž, darivatelj M & $36(25)$ \\
\hline $\begin{array}{l}\text { Dob pri transplantaciji (godine) } \\
\text { medijan (IQR) min. - maks. }\end{array}$ & \multicolumn{2}{|l|}{$\begin{array}{l}53(47-60) \\
27-84\end{array}$} \\
\hline $\begin{array}{l}\text { Vrijeme na dijalizi (godine) } \\
\text { medijan (IQR) min. - maks. }\end{array}$ & \multicolumn{2}{|l|}{$\begin{array}{l}3(1-5) \\
0-14\end{array}$} \\
\hline $\begin{array}{l}\text { Dob darivatelja (godine) } \\
\text { medijan (IQR) min. - maks. }\end{array}$ & \multicolumn{2}{|l|}{$\begin{array}{l}52(42-59) \\
16-75\end{array}$} \\
\hline $\begin{array}{l}\text { Hladna ishemija (sati) } \\
\text { medijan (IQR) min. - maks. }\end{array}$ & \multicolumn{2}{|l|}{$\begin{array}{l}14(12-16) \\
16-29\end{array}$} \\
\hline $\begin{array}{l}\text { Kreatininemija } 1 \text { godinu nakon } \\
\text { transplantacije } \mu \mathrm{mol} / \mathrm{I} \\
\text { medijan (IQR) min. - maks. }\end{array}$ & \multicolumn{2}{|l|}{$132(100-174)$} \\
\hline $\begin{array}{l}\text { Kreatininemija } 5 \text { godina nakon } \\
\text { transplantacije ( } \mu \mathrm{mol} / \mathrm{I}) \\
\text { medijan (IQR) min. - maks. }\end{array}$ & \multicolumn{2}{|l|}{$120(103-161)$} \\
\hline
\end{tabular}

$\mathrm{M}=$ muškarac; $\check{Z}$ = žena; IQR = interkvartilni raspon, od engl. interquartile range

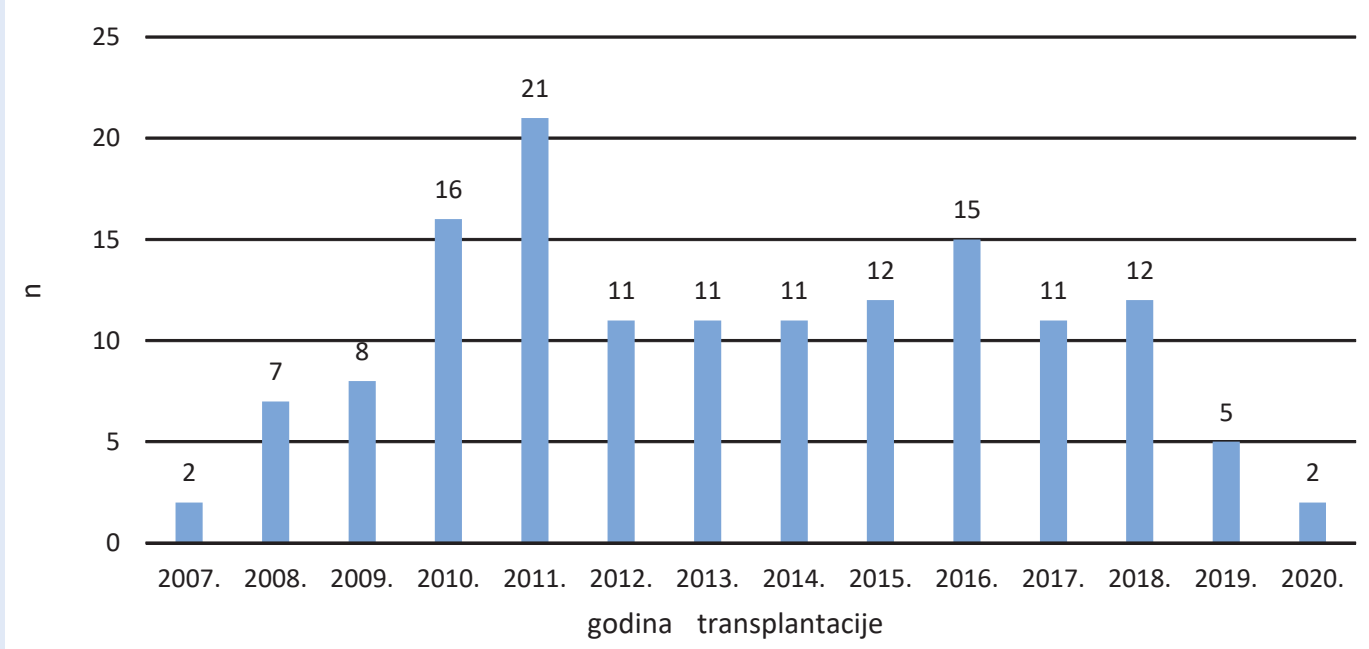

Slika 1. Broj transplantacija po godinama u Kliničkom bolničkom centru Osijek (od listopada 2007. do siječnja 2020.), $N=144$. 
Gubitak funkcije presatka imalo je 25 od 144 pacijenta $(17,4 \%)$. Najčešći uzrok tomu bilo je kronično odbacivanje presatka (17 pacijenata, $11,1 \%$ ), žilna tromboza presatka (3 pacijenta, $2,1 \%)$, te po 1 pacijent $(0,7 \%)$ zbog citomegalovirusne bolesti, BK nefropatije, krvarenja, emfizematoznog pijelonefritisa i nepoznatog uzroka.

Kreatininemija je, kao pokazatelj funkcije bubrežnog presatka, godinu dana nakon TX-a bila medijana $132 \mu \mathrm{mol} / \mathrm{I}$, IQR 100 - $174 \mu \mathrm{mol} / \mathrm{l}$ (od min. $48 \mu \mathrm{mol} / \mathrm{l}$ do maks. $492 \mu \mathrm{mol} / \mathrm{l})$.

Kreatininemija je nakon pet godina od TX-a bila medijana $120 \mu \mathrm{mol} / \mathrm{I}$, IQR 103 - $161 \mu \mathrm{mol} / \mathrm{I}$ (od min. $53 \mu \mathrm{mol} / /$ do maks. $341 \mu \mathrm{mol} / \mathrm{l})$.

Preživljenje presatka cenzurirano za smrt primatelja s funkcionirajućim presatkom nakon godine dana i nakon pet godina od TX-a prikazano je na slikama 2. i 3. Jednogodišnje preživljenje presatka cenzurirano za smrt s funkcionirajućim presatkom bilo je $93,8 \%$, a petogodišnje $88,9 \%$.

Ukupno preživljenje pacijenata s funkcionirajućim presatkom prikazano je na slici 4. Tijekom ukupnog vremena praćenja (medijan 7 godina, IQR 4 - 9 godina, od min. 0 godina do maks. 13 godina) preživljenje je bilo $86,8 \%$.

\section{RASPRAVA}

U istraživanje su bili uključeni svi pacijenti (144) kojima je učinjeno bubrežno presađivanje u KBC-u Osijek od početka transplantacijskog programa za bubreg do siječnja 2020. godine. Od 144 pacijenta, njih 60,4 \% bili su muškarci. Medijan dobi svih pacijenata u trenutku TX-a bio je 53 godine, od 27 do 84 godine. Prije bubrežnog TX-a 126 (88,5 \%) pacijenata bilo je na HD-u, a 18 (12,5\%) na PD-u, što je u skladu s europskim trendovima prikazanim u 2015. godini u godišnjem izvješću ERA - EDTA (engl. European Renal Association European Dialysis and Transplant Association, Europsko udruženje za nefrologiju, dijalizu i transplantaciju $)^{6}$. Većina ispitanika primila je bubrežni presadak prvi put (91\%).

$\mathrm{U}$ ovom istraživanju istražili smo jednogodišnje i petogodišnje preživljenje presatka do trenutka istraživanja, cenzurirano za smrt primatelja s funkcionirajućim presatkom, te ukupno preživljenje primatelja bubrežnog presatka do trenutka istraživanja i funkciju presatka nakon prve i pete godine na temelju kreatininemije.

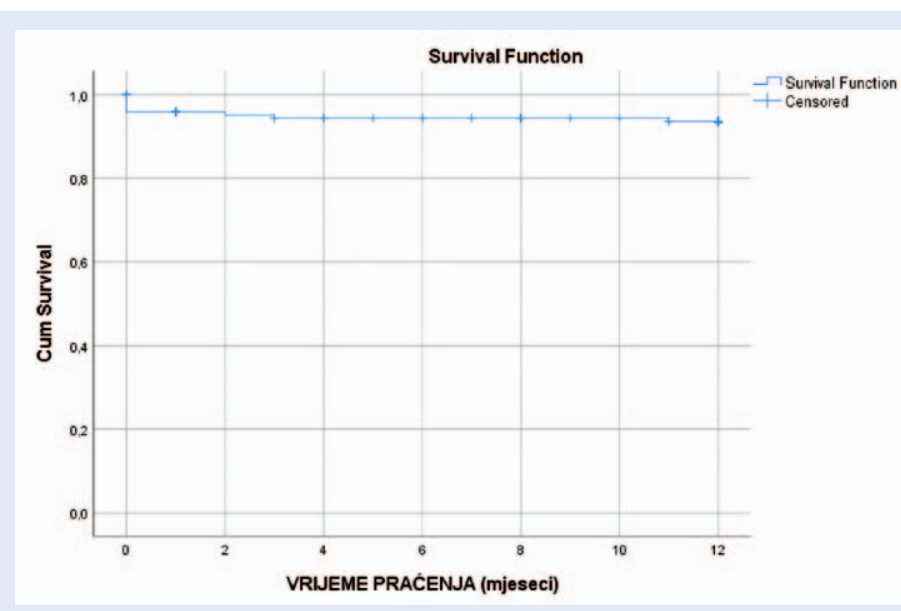

Slika 2. Jednogodišnje preživljenje presatka cenzurirano za smrt s funkcionirajućim presatkom, $\mathrm{N}=144, \mathrm{n}$ (gubitak presatka) = 9; jednogodišnje preživljenje $=93,8 \%$.

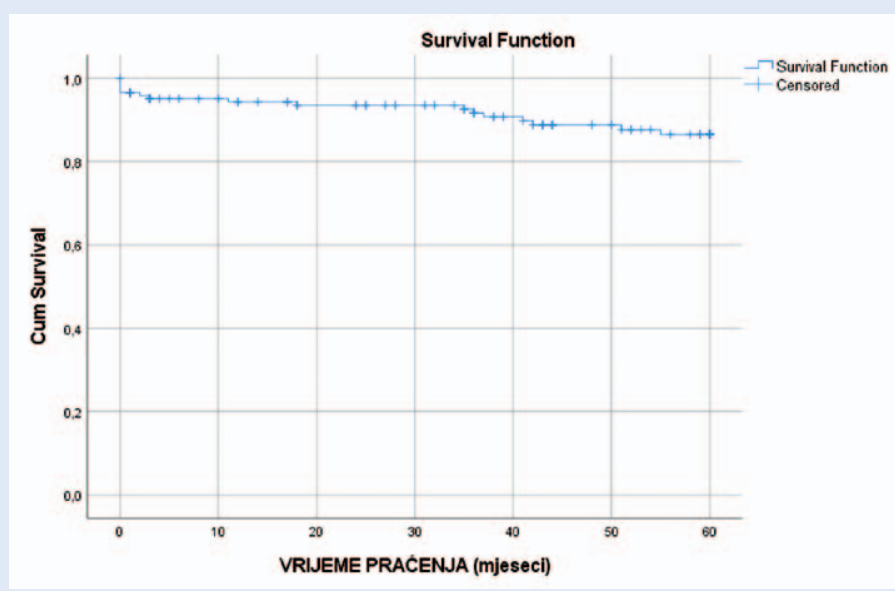

Slika 3. Petogodišnje preživljenje presatka cenzurirano za smrt s funkcionirajućim presatkom, $\mathrm{N}=144, \mathrm{n}$ (gubitak presatka) = 16; petogodišnje preživljenje $=88,9 \%$.

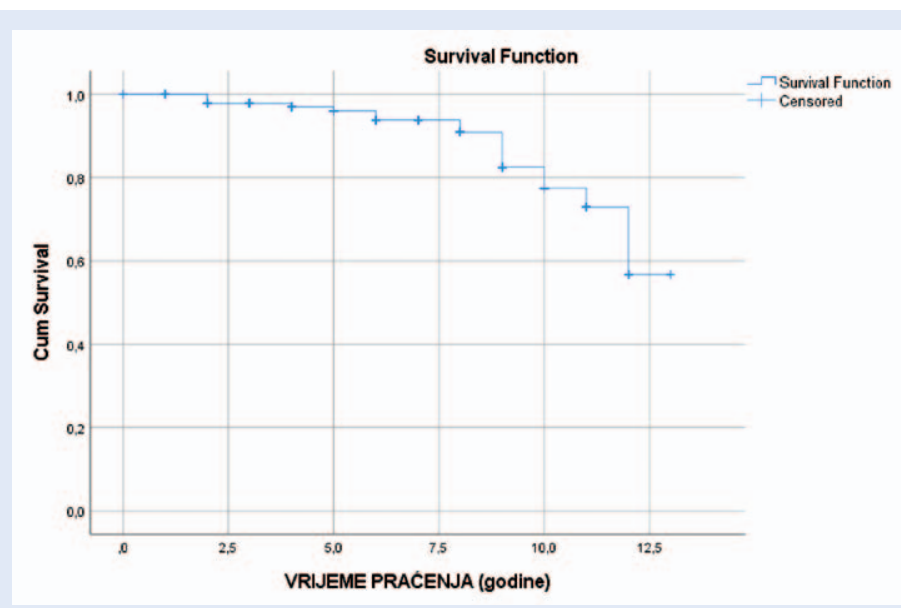

Slika 4. Preživljenje pacijenata ( $N=144)$ s funkcionirajućim presatkom je tijekom medijana praćenja 7 godina (interkvartilni raspon $4-9$ ), od min. 0 do max. 13 , bilo $86,8 \%$. 
Analizu preživljenja nužno je razumjeti kako bismo uspješno mogli interpretirati medicinsku literaturu s obzirom na to da se često koristi za procjenu preživljenja u medicinskim izvješćima i istraživanjima i na osnovi nje se donose važne odluke. Kod analize preživljenja presatka može se dogoditi jedan od sljedećih događaja: gubitak presatka, presadak funkcionira i pacijent se i dalje prati, smrt s gubitkom presatka i smrt s funkcionirajućim presatkom, pri čemu se oni $s$ funkcionirajućim presatkom mogu cenzurirati ${ }^{7}$. Važno je uspoređivati istovrsne ishode.

Jednogodišnje preživljenje presatka cenzurirano za smrt primatelja s funkcionirajućim presatkom u KBC-u Osijek iznosilo je $93,8 \%$, petogodišnje $88,9 \%$, a ukupno od trenutka TX-a 86,8\%. Uspoređujući rezultate preživljenja presatka cenzurirano za smrt primatelja s funkcionirajućim presatkom u KBC-u Osijek s rezultatima za Europu koji iznose za jednogodišnje preživljenje $91,1 \%$ i za petogodišnje 78,9\%, KBC Osijek je imao bolje ishode.

Jednogodišnje preživljenje presatka cenzurirano za smrt primatelja s funkcionirajućim presatkom u KBCO-u iznosilo je 93,8 \%, petogodišnje 88,9 \%, a ukupno od trenutka TX-a 86,8\%. Uspoređujući rezultate preživljenja presatka cenzurirano za smrt primatelja s funkcionirajućim presatkom u KBC-u Osijek s rezultatima za Europu, koji iznose za jednogodišnje preživljenje 91,1 \% i za petogodišnje 78,9 \%, KBC Osijek je imao bolje ishode ${ }^{6}$. Preživljenje pacijenata nakon bubrežnog TX-a značajno se poboljšalo u posljednjim desetljećima u odnosu na razdoblje prije toga. Sredinom 1970-ih godina jednogodišnje preživljenje je iznosilo oko 60 \% u starijih od 35 godina. Postotak jednogodišnjeg preživljenja 1990-ih značajno se popravio i iznosio je oko $90 \%{ }^{8,9}$. Preživljenja u KBC-u Osijek u skladu su s ovakvim suvremenim ishodima.

U našem istraživanju kreatininemija je, kao pokazatelj funkcije bubrežnog presatka, imala medijan $132 \mu \mathrm{mol} / /$ nakon prve godine, odnosno 120 $\mu \mathrm{mol} / \mathrm{I}$ nakon pete godine. Kreatinin u krvi nakon godine dana od TX-a dobar je prognostički čimbenik preživljenja presatka. $U$ istraživanju Fitzsimmonsa i suradnika pacijenti koji su imali vrijednost kreatinina više od $132 \mu \mathrm{mol} / \mathrm{l}$ nakon prve godine od TX-a su nakon 3 godine u $17 \%$ imali gubitak presatka, a ako je kreatinin nakon prve godine bio preko $176 \mu \mathrm{mol} / /$ gubitak presatka nakon tri godine bio je čak $26,5 \%^{10}$. Prema toj analogiji naši bi pacijenti mogli imati povoljnu i dugoročniju prognozu.

I prema Rončeviću je pokazatelj funkcije presatka - glomerulska filtracija (GF), za prva 122 primatelja u KBC-u Osijek iznosila prosječno 49,1 ml/min (standardna devijacija 20,1), u skladu s ovdje prikazanom razinom funkcije u ukupno 144 pacijen$\mathrm{ta}^{11}$. Istraživanje koje je provedeno $\mathrm{u}$ dva transplantacijska središta u Francuskoj (Saint-Etienne i Pariz) na 825 stabilnih primatelja bubrežnog presatka pokazalo je da je srednja vrijednost GF-a iznosila $50 \mathrm{ml} / \mathrm{min}$, sa standardnom devijacijom $19 \mathrm{ml} / \mathrm{min}^{12}$. Drugo istraživanje provedeno na Klinici Mayo u SAD-u pokazalo je da je vrijednost GF-a u 1303 funkcionirajuća presatka iznosila 50,9 ml/min sa standardnom devijacijom od 14 $\mathrm{ml} / \mathrm{min}^{13}$. Iz toga se vidi da su pacijenti u KBC-u Osijek imali komparabilne vrijednosti GF-a s obzirom na istraživanja provedena u Europi i SAD-u. Smrt pacijenata s funkcionirajućim presatkom jedan je od glavnih razloga kasnijeg gubitka presatka. Srčanožilne, zloćudne bolesti i infekcije tri su vodeća uzroka smrti s funkcionirajućem presatkom u SAD-u ${ }^{14,15}$. Praćenjem više od 10000 transplantiranih pacijenata $u$ jednom središtu u Brazilu, kao vodeći urok smrti s funkcionirajućem presatkom bila je infekcija, u $53 \%$ pacijenata, osobito u prvoj godini nakon TX-a ${ }^{16,17}$. Prema engleskom registru iz 2012. godine smrtnost nakon TX-a zbog infekcije bila je oko $23 \%^{18}$. Od 144 pacijenta, u našem istraživanju, smrtnost s funkcionirajućim presatkom bila je 13,2 \%, najčešće od infekcije i srčanožilnih uzroka.

\section{ZAKLJUČCI}

Transplantacijski program za bubreg KBC-a Osijek postoji unatrag nepunih trinaest godina tijekom kojih su do 31. siječnja 2020. učinjena 144 TX-a s umrlog darivatelja. Uspješnost transplantacije bubrega u KBC-u Osijek komparabilna je s objavljenim rezultatima za druga područja. Jednogodišnje i petogodišnje preživljenje pacijenata i presatka bilo je slično preživljenju u drugim europskim zemljama. 
Izjava o sukobu interesa: Autori izjavljuju da ne postoji sukob interesa.

\section{LITERATURA}

1. Utvić V. Povijest bolničkih ustanova u Osijeku od 1874. 1974. Osijek: Opća bolnica Osijek; 1974.

2. Tucak A, Fatović-Ferenčić S. Povijesni razvoj Medicinskog fakulteta Osijek. U: Filaković P (ur.) 10 godina Medicinskog fakulteta 1998. - 2008. Osijek: Medicinski fakultet Sveučilište J. J. Strossmayer Osijek, 2008;13-21.

3. Eurotransplant [Internet]. Leiden: factsheet, reference date: january 28, 2020. (cited 2020 Jan 28). Available from: https://www.eurotransplant.org/wp- content/uploads/2019/12/Factsheet-final.pdf.

4. Zivcic-Cosic S, Busic M, Zupan Z, Pelcic G, Anusic Juricic $M$, Jurcic $Z$ et al. Development of the Croatian model of organ donation and transplantation. Croat Med J 2013;54:65-70.

5. Ministarstvo zdravstva [Internet]. Prikaz rezultata nacionalnog transplantacijskog programa 2017. (cited 2020.Jan 28). Available from: https://zdravlje.gov.hr/ UserDocsImages/dokumenti/Tekstovi\%20razni/Rezultati\%20Nacionalnog\%20transplantacijskog\%20programa\%202017_hr.pdf.

6. Kramer A, Pippias M, Noordzij M, Stel VS, Afentakis N, Ambuhl PM et al. The European Renal Association - European Dialysis and Transplant Association (ERA-EDTA) Registry Annual Report 2015: a summary. Clin Kidney J 2018;11:108-22.

7. Barraclough H, Simms L, Govindan R. Biostatistics primer: what a clinician ought to know: hazard ratios. J Thorac Oncol 2011;6:978-82.

8. Briggs JD. Causes of death after renal transplantation. Nephrol Dial Transplant 2001;16:1545-9.

9. Bentata Y. Tacrolimus: 20 years of use in adult kidney transplantation. What we should know about its nephrotoxicity. Artif Organs 2020;44:140-152.
10. Fitzsimmons W, Hompson D, Hariharan S, Van Veldhuisen P. Serum creatinine as a surrogate endpoint for grai loss in kidney transplantation: validation efforts from multicenter trials. Am J Transplant 2002;2:272.

11. Rončević $R$. Ishodi bubrežnog presađivanja u kliničkom bolničkom centru Osijek. Osijek: Medicinski fakultet, 2018. Graduate work.

12. Masson I, Flamant M, Maillard N, Rule AD, Vrtovsnik F, Peraldi MN et al. MDRD versus CKD-EPI equation to estimate glomerular filtration rate in kidney transplant recipients. Transplantation 2013;95:1211-7.

13. Lorenz EC, El-Zoghby ZM, Amer H, Dean PG, Hathcock MA, Kremers WK et al. Kidney allograft function and histology in recipients dying with a functioning graft. Am J Transplant 2014;14:1612-8.

14. Cosio FG, Hickson LJ, Griffin MD, Stegall MD, Kudva Y. Patient survival and cardiovascular risk after kidney transplantation: the challenge of diabetes. Am J Transplant 2008;8:593-9.

15. Rangaswami J, Mathew RO, Parasuraman R, Tantisattamo E, Lubetzky M, Rao $S$ et al. Cardiovascular disease in the kidney transplant recipient: epidemiology, diagnosis and management strategies. Nephrol Dial Transplant 2019:34:760-773.

16. De Castro Rodrigues Ferreira F, Cristelli MP, Paula MI, Proenca $\mathrm{H}$, Felipe $\mathrm{CR}$, Tedesco-Silva $\mathrm{H}$ et al. Infectious complications as the leading cause of death after kidney transplantation: analysis of more than 10,000 transplants from a single center. J Nephrol 2017;30:601-6.

17. Awan AA, Niu J, Pan JS, Erickson KF, Mandayam S, Winkelmayer WC et al. Trends in the causes of death among kidney transplant recipients in the United States (19962014). Am J Nephro 2018;48:472-481.

18. Pruthi R, Steenkamp R, Feest T. UK Renal Registry 16th annual report: chapter 8 survival and cause of death of UK adult patients on renal replacement therapy in 2012: national and centre-specific analyses. Nephron Clin Pract 2013;125:139-69. 